\title{
RETICULATED PYTHON Malayopython reticulatus (SCHNEIDER 1801) : RESCUE, RECOVERY AND RECENT SIGHTINGS FROM GREAT NICOBAR ISLAND-A CONSERVATION APPROACH
}

\author{
S. Rajeshkumar ${ }^{1 *}$, C. Raghunathan ${ }^{1}$ and Kailash Chandra $^{2}$ \\ ${ }^{1}$ Zoological Survey of India, Andaman and Nicobar Regional Centre \\ Port Blair-744 102, Andaman and Nicobar Islands, India \\ ${ }^{2}$ Zoological Survey of India, M-Block, New Alipore, Kolkatta-700 053, India \\ *Email: rajeshkumar0802@gmail.com
}

\begin{abstract}
Previously the Reticulated python was recorded by few researchers from Nicobar Islands In 2006, four individuals were observed, but there was no more information added in their literature about sightings in Great Nicobar Island. Pythons were considered as an uncommon and rare encountered species in India also to the Nicobar Islands. Pythons considered relatively rare appearance to have declined due to frequent eradication by habitat destruction On $25^{\text {th }}$ August 2013, first individual of reticulated python was caught by the local people at Govind Nagar (Lat: 07 $00.074^{\prime} \mathrm{N}$, Long: $093^{\circ}$ $54.128^{\prime}$ E, Altitude at 49.4 meter) in Great Nicobar Island The second one was rescued on $31^{\text {st }}$ August 2013 in the same area by the local people. Both the recovered individuals were appeared as juvenile. Investigations on population census of this threatened species and their habitat have been felt from the present incidences.
\end{abstract}

Key words:

\section{INTRODUCTION}

Snakes are perhaps one of the most difficult vertebrate groups to survey (Groombridge and Luxmoore 1991). Reticulated Python Malayopython reticulatus (Schneider 1801) is rare, largest and least recorded snake in India (Sharma 2003, Whitaker and Captain 2004). Two species of pythons (Reptilia; Squamata; Pythonidae) are reported in India i.e., Indian Rock Python (Python molurus) and Reticulated Python (Python reticulatus). After taxonomic changes made by Reynolds et al. (2014) the name has been changed as Malayopython reticulatus (Schneider 1801). Python is locally (in Nicobarese) called as 'Yammai' or 'Tulanth' (Chandi 2006) and 'hmøsøy' (in Shobængs) literally it means snake in Shompen's linguistics (van Driem 2010). Here, we provide the morphometric measurements of two individuals of recovered reticulated python (Table 1). We deliberated with its occurrence of this rare species after tsunami from Great Nicobar Island, India. This article also explained about threats posed for the reptiles and its conservation strategies. 
Table 1. External measurements of rescued reticulated pythons from Great Nicobar Island 2013.

\begin{tabular}{llcc}
\hline & Morphometric measurements & Individual 1 & Individual 2 \\
\hline SVL & Snout Vent Length & $1810 \mathrm{~mm}$ & $1140 \mathrm{~mm}$ \\
TaL & Tail Length & $250 \mathrm{~mm}$ & $210 \mathrm{~mm}$ \\
TL & Total Length & $2060 \mathrm{~mm}$ & $1350 \mathrm{~mm}$ \\
HLTOT & Total length of Head & $81 \mathrm{~mm}$ & $62 \mathrm{~mm}$ \\
HWTOT & Head width & $55 \mathrm{~mm}$ & $44 \mathrm{~mm}$ \\
ED & The diameter of the orbit & $2.3 \mathrm{~mm}$ & $2.2 \mathrm{~mm}$ \\
BW & Body width & $148 \mathrm{~mm}$ & $94 \mathrm{~mm}$ \\
\hline
\end{tabular}

\section{Distribution}

Reticulated python distributed throughout South and Southeast Asia and its associated Islands, during the Pleistocene period's sea-level changes probably to the isolation of these taxa (Auliya et al. 2002). Hence that far out across the sea it ranges from western Bangladesh, Myanmar, Thailand, Vietnam, Cambodia, Indonesia, Malaysia, Singapore and Philippines (Groombridge and Luxmoore 1991, David and Vogel 1996, Gaulke et al. 1998, Das 2002). In India, it has very limited distribution, it occupies in the Nicobar group of Islands also rarely recorded in North eastern part of India (Daniel 1983, Tikader 1983, Whitaker and Captain 2004). However, it was recently recorded from Baidyabati canal in the Ganges river of Hooghly, West Bengal (Mukherjee et al. 2012). No other records are available in mainland India. In Andaman and Nicobar Islands, the occurrence was restricted to Nicobar group of Islands isolated in Northern Nicobar Island (Car Nicobar), Central Nicobar Islands (Bompoka, Tarasa, Trinkat, Tillanchong, Katchal, Kamorta, Nancowry) and Southern Nicobar Islands (Little Nicobar, Menchal and Great Nicobar) (Das 1999, Vijayakumar and David 2006).

\section{Previous records from Nicobar Islands}

Previously the Reticulated python was recorded by few researchers from Nicobar Islands (Blyth 1846, Biswas and Sanyal 1977, 1980,
Daniel 1983, Bhaskar and Rao 1992, Das 1999, Whitaker and Captain 2004, Vijayakumar and David 2006). In 2006, four individuals were observed (Vijayakumar and David 2006), but there was no more information added in their literature about sightings in Great Nicobar Island. Pythons were considered as an uncommon and rare encountered species in India also to the Nicobar Islands (Daniel 1983, Sharma 2003, Whitaker and Captain 2004, Vijayakumar and David 2006). Besides, a very few observations on the anthropogenic pressure was noticed previously by Bhaskar and Rao (1992) and Vijayakumar and David (2006). Pythons considered relatively rare appearance to have declined due to frequent eradication by habitat destruction (Vijayakumar and David 2006). Presently threats are increased against faunal communities by anthropogenic pressure.

\section{Observation and discussion}

A very few observations was made before and after tsunami from these Islands. Although, no single individual of python sighting in Menchal Island after 2004 tsunami (Chandi 2006). Obviously little known vulnerable Giant Robber Crab Birgus latro, reticulated Python Python reticulatus and Malayan Box Turtle Cuora amboinensis are seriously affected due to tsunami, almost these fauna have been impacted very badly than the megapode (Sekhsaria 2009). Reticulated 
python sightings were very rare and its population was drastically reduced due to the impact of December 2004 tsunami. After tsunami the python population and its status was unknown also there was no authentic sight records in these Nicobar Islands.

On $25^{\text {th }}$ August 2013, first individual of reticulated python was caught by the local people at Govind Nagar (Latitude: $07^{\circ} 00.074^{\prime} \mathrm{N}$, Longitude: $093^{\circ} 54.128^{\prime} \mathrm{E}$, Altitude at 49.4 meter) in Great Nicobar Island (Fig. 1a), it was found near to human settlements visited for feeding chicks. People were tried to kill the snake (Fig. 1b, c and d), by that time some of the local people informed us. It was identified as reticulated python, immediately the snake was rescued (Fig. 1e) and released after taking morphometric measurements and photographs on the same day at the East west road, $12^{\text {th }} \mathrm{km}$, in reserve forest of Great Nicobar Biosphere Reserve (Fig. 1f) with an information to forest officials. The first recovered python was at the length of 6.7 feet $(206 \mathrm{~cm})$ with presence of hemipenis appears to be male. The second one was rescued on $31^{\text {st }}$ August 2013 in the same area by the local people. They brought it to our camp in the late evening; it was tied with nylon rope in head (Fig. 1d). Immediately the rope was cut off and the python released in reserve forest at Govind nagar area of Great Nicobar Island after taking few measurements and photographs. It was at the length of 4.4 feet $(135 \mathrm{~cm})$. Both the recovered individuals were appeared as juvenile. The habitat was confined to rainforests, woodlands, and nearby grasslands associates with streams, rivers, lakes, occasionally entered into human settlements, paddy fields, hills, rocks (Bourret 1936, Mehrtens 1987). Thus, they supposed to have a tendency to live near human habitation for survival.

\section{Threats and conservation}

Reticulated python was considered as threatened species in India (Tikader 1983) because they used as a food and viewed as pest; hence they were killed wherever encountered by the people (Vijayakumar and David 2006). The snakes have been already over-exploited for its skin and flesh by local settlers and natives that may lead to its present status as an endangered species (Bhaskar and Rao 1992). In Southeast Asian countries like Indonesia, Malaysia, Lao and Philippines, pythons are traded for leather industries (Shine et al. 1999, Fredriksson 2005). But there was no evidence of exporting of python skin was seen in Great Nicobar Island. This Island, two native tribes are living (Shompens and Nicobari) in this island and they are hunting large pythons for meat (Chandi 2006, Vijayakumar and David 2006). Nowadays Nicobari people are well modernized, involving cultivation of agriculture and fishing rather than hunting activities. Shompens and a few settlers are continuously involved in hunting activities. Apart from Pythons, and other wild animals like wild boar (Sus scrofa nicobaricus), saltwater crocodile (Crocodylus porosus), water monitor lizard (Varanus salvator) and all species of pigeons are hunted especially for food as meat and a few medicinal purposes. Reticulated Python protected under the Indian Wildlife (Protection) Act 1972, listed as Schedule-I, Part-II (Anonymous 1972) also it was listed in Appendix-II in CITES, but not evaluated in IUCN Red list (Groombridge and Luxmoore 1991, Auliya et al. 2002). Besides, the aboriginal tribes of Andaman and Nicobar Islands are exempted from Wildlife (Protection) Act 1972 under section 56 they have hunting rights in India (Anonymous 1972). Hence an effective measures to be taken to control the hunting activities against this vulnerable species through awareness program in this ecologically sensitive areas. 


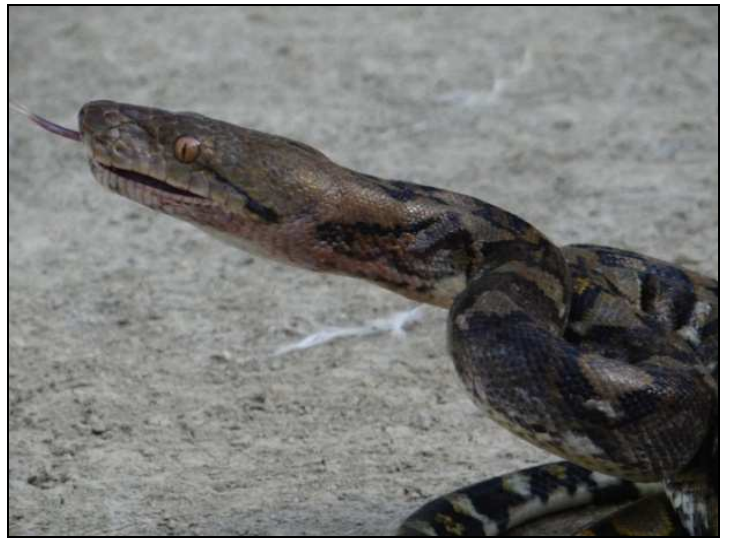

A

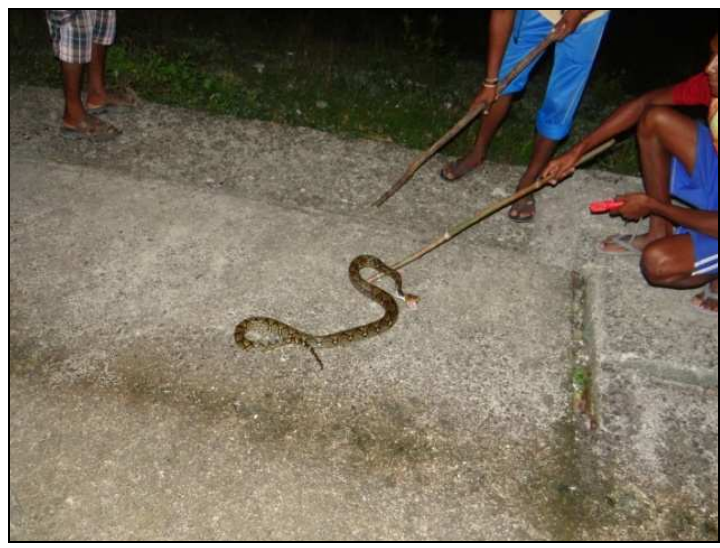

C

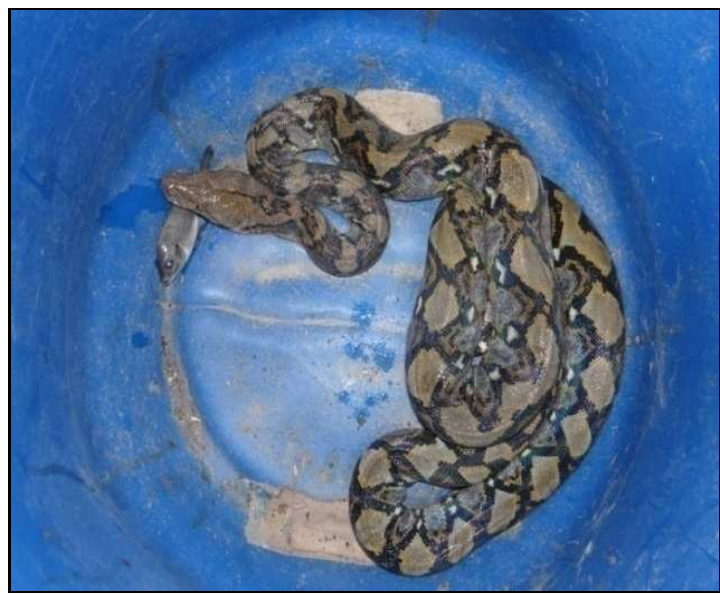

国

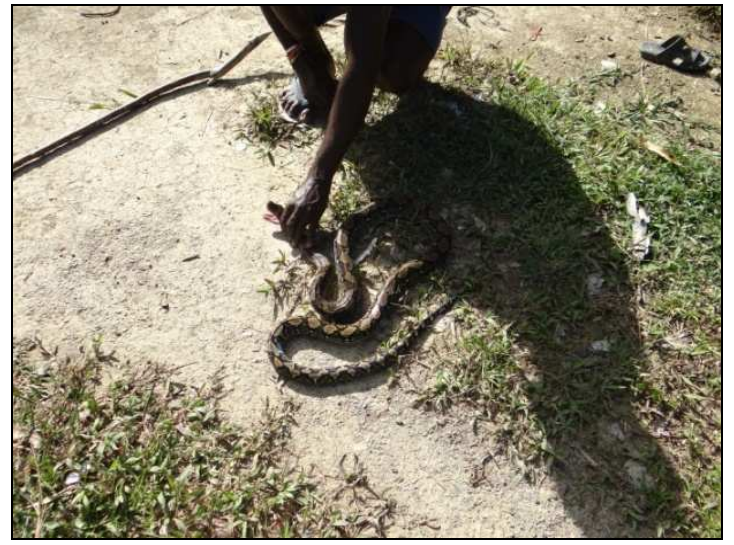

B

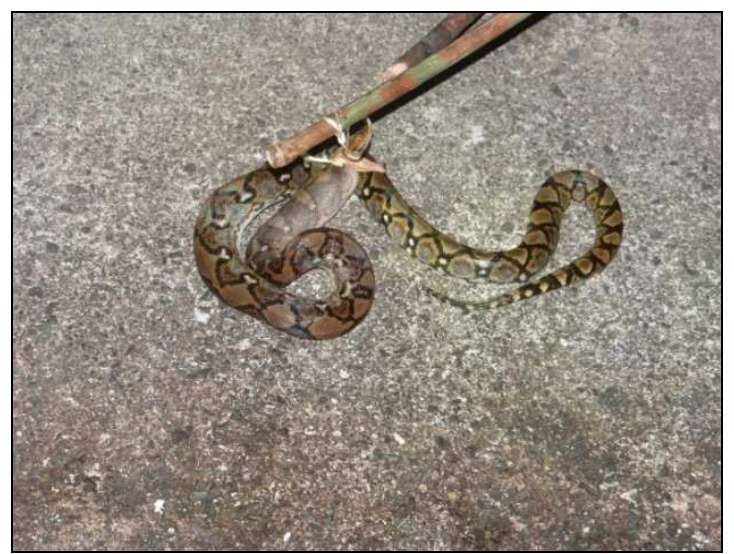

D

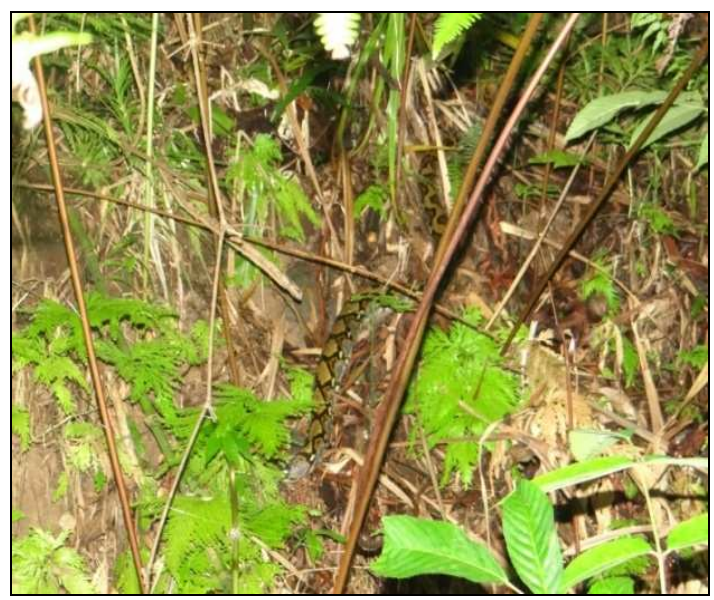

E

Fig. 1. (A) Reticulated python Malayopython reticulates in Great Nicobar Island, (B and C) Python being captured by locals, (D) Snake head tied with nylon rope and threatening pose, (E) Python rescued and kept in plastic container, (F) Python released in wild. 


\section{CONCLUSION}

Further population census is an urgent requirement for this threatened species. Moreover, species specific management practice, initiation of community interaction programs at local and regional level to improve reptile conservation in this biome.

\section{ACKNOWLEDGEMENT}

The authors are grateful to Ministry of Environment, Forest and Climate Change, Government of India for financial assistance.

\section{REFERENCES}

Anonymous. 1972 (Amended 2006). Wildlife (Protection) Act. India.

Arma, R.C. 2003. Handbook-Indian Snakes. Zoological Survey of India, 292 p.

Auliya, M., P. Mausfeld, A. Schmitz and W. Böhme. 2002. Review of the reticulated python (Python reticulatus Schneider, 1801) with the description of new subspecies from Indonesia. Naturwissenschaften 89:201-213.

Baskar, S. and G.C. Rao. 1992. Present status of some endangered animals in Nicobar Islands. Journal of Andaman Science Association 8(2):181-186.

Biswas, S. and D.P. Sanyal. 1977. Notes on the Reptilia collection from the Great Nicobar Island during Great Nicobar Expedition in 1966. Records of the Zoological Survey of India 72:107-124.

Biswas, S. and D.P. Sanyal. 1980. A report on the reptilian fauna of Andaman and Nicobars Islands in the collection of Zoological Survey of India. Records of the Zoological Survey of India 77:255-292.

Blyth, E. 1846. Notes on the fauna of the Nicobar Islands; Reptilia. Journal of Asiatic Society Bengal 15:367-379.
Bourret, R. 1936. Les serpents de l'Indochine, vol.II. Catalogue systematique descriptive, 505. Toulouse: Henri Basayau et Cie.

Chandi, M. 2006. The use and knowledge of herpatofauna on Little Nicobar Island, India. Conservation and Society 4(1):155-165.

Daniel, J.C. 1983. The Book of Indian Reptiles. Bombay Natural History Society, Bombay, $141 \mathrm{p}$.

Das, I. 1999. Biogeography of the amphibians and reptiles of the Andaman and Nicobar Islands. In: Tropical Island Herpetofauna. Origin, Current Diversity and Conservation. (ed.) Ota, H. Elsevier Science B.V., Amsterdam, Developments in Animal and Veterinary Sciences. 29:43-77.

Das, I. 2002. A Photographic Guide to Snakes and Other Reptiles of India. New Holland Publishers (UK) Ltd., London-Cape TownSydney-Auckland.

David, P. and G.Vogel. 1996. The Snakes of Sumatra. An Annotated Checklist and Key with Natural History Notes. Edition Chimaira, Frankfurt-am-Main.

Fredriksson, G.M. 2005. Predation on Sun Bears by reticulated Python in East Kalimantan, Indonesian Borneo. Raffles Bulletin of Zoology 53(1):165-168.

Gaulke, M., F. Abel, W. Erdelen and U. Fritz. 1998. Notes on the herpetofauna of North Sumatra. Hamadryad 23(1):78-82.

Groombridge, B. and R. Luxmoore. 1991. Report to the Convention on International Trade in Endangered Species of Wild Fauna and Flora Secretariat on Python of South-East Asia: A Review of Distribution, Status and Trade in Three Selected Species. CITES, Switzerland, $127 \mathrm{p}$.

Mehrtens, J.M. 1987. Living Snakes of the World in Color. Sterling Publishers, New York, 480 p.

ECOPRINT VOL 22, 2015 
Mukherjee, S., V. Santra and G. Aditya. 2012. Reticulated Python, Python reticulatus (Schneider 1801) in Hooghly, West Bengal, India. Proceedings of the Zoological Society 65(2):114-117.

Reynolds, R.G., M.L. Niemiller and L.J. Revell. 2014. Toward a tree-of-life for the boas and pythons: Multilocus species-level phylogeny with unprecedented taxon sampling. Molecular Phylogenetics and Evolution 71:201-213.

Sekhsaria, P. 2009. When Chanos chanos became tsunami macchi: The post-December 2004 scenario in the Andaman and Nicobar islands. Journal of the Bombay Natural History Society 106(3):256-262.

Shine, R., A. Ambariyanto, P.S. Harlow and Mumpani. 1999. Reticulated pythons in Sumatra: Biology, harvesting and sustainability. Biological Conservation 87:349-357.
Tikader, B.K. 1983. Threatened Animals of India. Zoological Survey of India, Calcutta, India, $307 \mathrm{p}$.

van Driem, G. 2010. The Shompens of Great Nicobar Island: New linguistic and genetic data, and the Austroasiatic homeland revisited. In: Austroasiatic Linguistics: Proceedings of the Third International Conference on Austroasiatic Linguistics. (eds.) Nagaraja, K.S and K. Mankodi. Rathinasabapathy Elangaiyan Memorial Vol. Central Institute of Indian Languages, Mysore, India, pp. 224-259.

Vijayakumar, S.P. and P. David. 2006. Taxonomy, natural history and distribution of the snakes of Nicobar Islands (India) based on new materials and with an emphasis on endemic species. Russian Journal of Herpetology 13(1):11-40.

Whitaker, R. and A. Captain. 2004. Snakes of India. The Field Guide. Draco Books, Chengalpattu, pp. 78-79. 